\title{
New record of Akashiwo sanguinea (Dinophyta) in the tropical estuarine waters of Northeastern Brazil (Western Atlantic)
}

\author{
Koening, ML. ${ }^{a}{ }^{*}$, Flores Montes, MJ. ${ }^{a}$, Eskinazi Leça, E. ${ }^{b}$ and Tiburcio, ASXS. ${ }^{a}$ \\ ${ }^{a}$ Departamento de Oceanografia, Universidade Federal de Pernambuco \\ Av. Arquitetura s/n, Cidade Universitária, CEP 50740-550 Recife - PE, Brasil \\ ${ }^{\mathrm{b}}$ Departamento de Biologia, Universidade Federal Rural de Pernambuco \\ Rua Dom Manoel de Medeiros s/n, Dois Irmãos, CEP 52171-900 Recife - PE, Brasil \\ * e-mail: koening@ufpe.br
}

Received: March 9, 2012 - Accepted: October 29, 2012 - Distributed: February 28, 2014

(With 4 Figures)

\begin{abstract}
This study reports the occurrence and the effect of the environmental factors on the spatial and temporal distribution of the dinoflagellate Akashiwo sanguinea (Hirasaka) Hansen \& Moestrup in estuarine waters of northeastern Brazil. Samples were collected at seven stations from March 2007 to February 2008 during high tide and low tide, using Van Dorn bottles. The samples were immediately fixed with Lugol and analyzed with the Utermöhl method. Water samples were also collected for the identification of the hydrological characteristics of the area. Akashiwo sanguinea occurred throughout the annual cycle and at all sampling sites with densities ranging between 5 and $410 \times 10^{3}$ cells. $\mathrm{L}^{-1}$. The highest densities were recorded at low tide, especially during the months of the rainy season (July: $210 \times 10^{3}$ cells. $\mathrm{L}^{-1}$; August: $410 \times 10^{3}$ cells. $\mathrm{L}^{-1}$ ). Density values were within the normal range and blooms were not detected. Despite being common in the area, the species showed preference for sites with high concentrations of orthophosphate and total dissolved phosphorus and with salinity in the mesohaline regime.
\end{abstract}

Keywords: Akashiwo sanguinea, dinoflagellate, distribution, estuarine waters, northeastern Brazil.

\section{Novo registro de Akashiwo sanguinea (Dinophyta) em águas estuarinas tropicais do nordeste do Brasil (Atlântico Ocidental)}

\section{Resumo}

Este estudo relata a ocorrência e o efeito dos fatores ambientais na distribuição espacial e temporal do dinoflagelado Akashiwo sanguinea (Hirasaka) Hansen et Moestrup em águas estuarinas do Nordeste do Brasil. As amostras foram coletadas em sete estações, durante o período de março 2007 a fevereiro 2008 durante os regimes de preamar e baixamar, com o auxílio de garrafas tipo Van Dorn. As amostras foram imediatamente fixadas com lugol e analisadas pelo método de Utermöhl. Amostras de água foram também coletadas para a identificação das características hidrológicas da área. Akashiwo sanguinea ocorreu em todo o ciclo anual e em todos os locais de coleta com densidade variando de 5 a 410 cells. $L^{-1} \times 10^{3}$, sendo as maiores densidades registradas na baixa-mar, principalmente, durante os meses do período chuvoso (julho 210 cells. $\mathrm{L}^{-1} \times 10^{3}$, agosto 410 cells.L $\mathrm{L}^{-1} \times 10^{3}$ ). Os valores quantitativos estiveram dentro dos padrões normais, não tendo sido detectados florescimentos com conotações de blooms. Apesar de ser frequente na área, a espécie mostrou preferência pelos locais com maiores concentrações de ortofosfato dissolvido e fósforo total dissolvido e salinidade compreendida no regime mesoalino.

Palavras-chave: Akashiwo sanguinea, dinoflagelado, distribuição, águas estuarinas, nordeste do Brasil.

\section{Introduction}

Akashiwo sanguinea (Hirasaka) Hansen \& Moestrup is the type species of Akashiwo, a genus of naked Dinophyta described by Daugbjerg et al. (2000). This classification is based on ultrastructure and DNA analysis of dinoflagellate samples. The species has the basionym Gymnodinium sanguineum Hirasaka and several synonyms: Gymnodinium splendens Lebour, Gymnodinium nelsonii Martin, and Glenodinium sanguineum Marchesoni. It is a planktonic, cosmopolitan, euryhaline and eurythermal species commonly found in coastal and estuarine areas in climates ranging from tropical to temperate (Nakamura et al., 1982; Horner et al., 1997; Gómez and Boicenco, 2004). Although Akashiwo sanguinea is not related to the production of toxins, blooms of the species have coincided with depletion of dissolved oxygen and mortality of fish and shellfish in various parts of the world (Hirasaka, 1922; Hallegraeff, 1993; GómezAguirre, 1998; Robichaux et al., 1998; Wu et al., 2000). 
In Brazil, the only records of the species are for tropical coastal lagoons in the southeastern portion of the country. The existing records are for two lagoons located in Rio de Janeiro: Imboassica (Melo et al., 2007) and Barra (Domingos and Menezes, 1998).

The aim of this paper was to highlight the first record of Akashiwo sanguinea in estuarine waters in the state of Pernambuco and analyze the effects of the environmental factors on the spatial and annual variation of the species in a northeastern tropical area of Brazil.

\section{Materials and Methods}

The samples were collected in the tropical estuarine ecosystem of Itamaracá Island, which is located on the north coast of Pernambuco (7³4'00" - 755'16”S and $\left.34^{\circ} 48^{\prime} 48^{\prime \prime}-34^{\circ} 52^{\prime} 24^{\prime \prime} \mathrm{W}\right)$. This ecosystem is formed by the Santa Cruz Channel, a $20 \mathrm{~km}$ long U-shaped feature connected to the Atlantic Ocean, and its tributary rivers: Catuama, Carrapicho, Arataca, Botafogo, and Congo (Figure 1). The strong inflow of marine waters through the two ends of the Channel determines the salinity regime, which varies between mesohaline and euhaline. The discharge from the tributary rivers and the morphobathymetry of the channel are the two main factors that govern the residual circulation of the Santa Cruz Channel. The $36 \mathrm{~km}^{2}$ wetland has a direct effect on the productivity of the entire estuarine system (Medeiros and Kjerfve, 1993).

According to the Köppen climate classification system, the climate of the estuarine ecosystem is Am with tropical humidity and an annual rainfall of approximately 2.000 $\mathrm{mm}$. The area experiences a tropical monsoon climate with

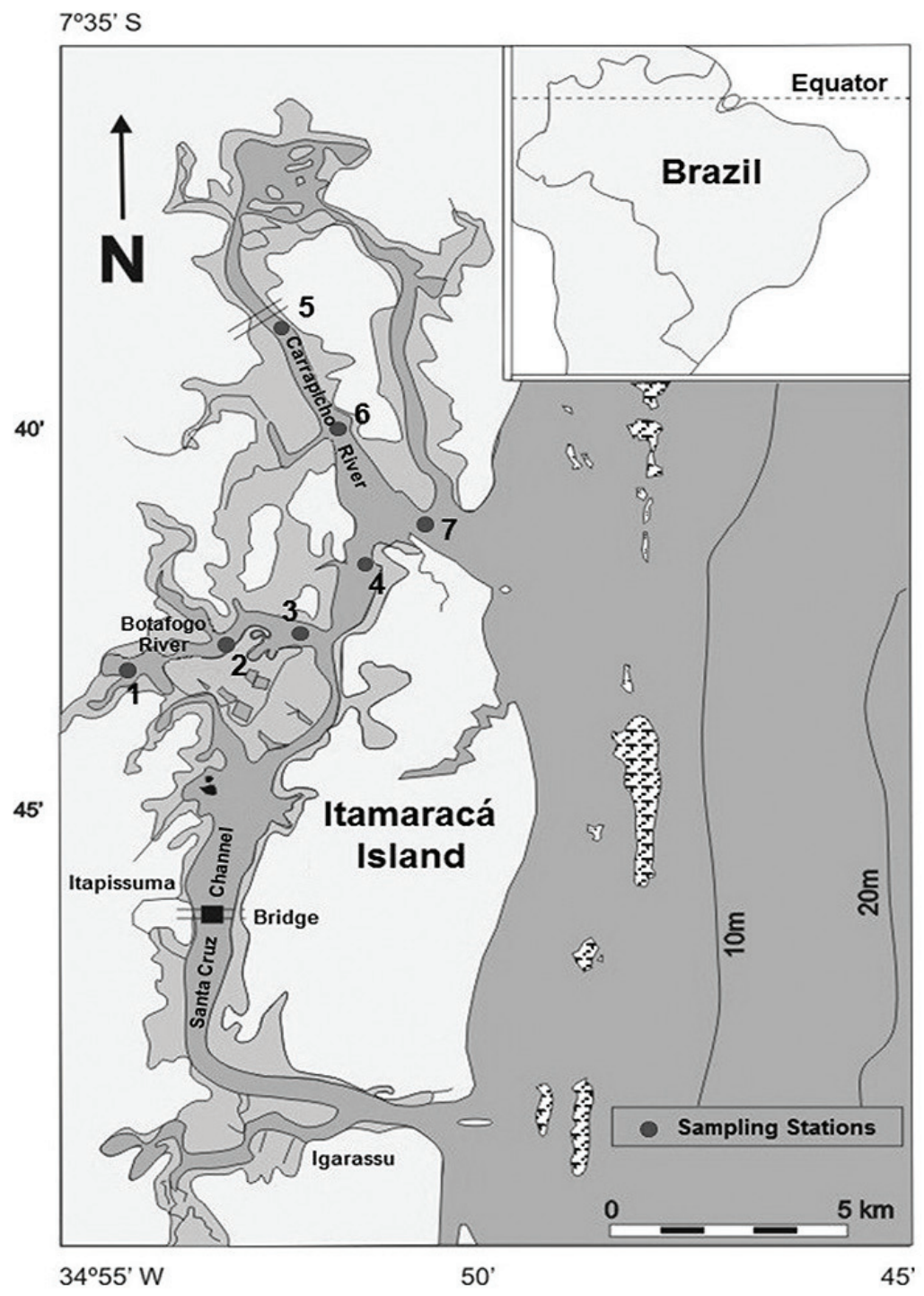

Figure 1. Map of Itamaracá Island (Northeastern-Brazil), showing the sampling stations. 
a rainy season occuring between March and August (with precipitation above $100 \mathrm{~mm}$ ) and a dry season occurring between September and February (with precipitation below $100 \mathrm{~mm}$ ). The region is warm, with annual average air temperatures between $22^{\circ} \mathrm{C}$ and $26^{\circ} \mathrm{C}$. Easterly trade winds prevail in the region from October to March and south-southeasterly trade winds are prevalent from April to September. Average wind speeds are between $6.1 \mathrm{kn}$ and 9.3 $\mathrm{kn}$ (Koening et al., 2002). The ecosystem is threatened by numerous anthropogenic activities, including, the release of industrial waste, pollution from sewage, poaching, tourism, real estate development, and implementation of aquaculture projects (Medeiros et al., 2001).

Seven sampling stations were established: three in the Botafogo River estuary (stations 1, 2, and 3), one in the Santa Cruz Channel (station 4), two in the Carrapicho River estuary (stations 5 and 6), and one at the confluence of the two river estuaries (station 7). Samples were collected on a monthly basis from March 2007 to February 2008 during high tide and low tide using Van Dorn bottles. The samples were immediately fixed with Lugol. Cell counts were performed utilizing the Utermöhl method with an inverted microscope (Zeiss Axiovert). To the taxonomic identification Steidinger and Tangen (1997) was adopted.

The following abiotic parameters were also determined: water temperature, measured with a centigrade thermometer; water transparency, measured using Secchi disk disappearance and turbidity with a turbidimeter (a nephelometric meter); salinity, determined by the Mohr-Knudsen method (Strickland and Parsons, 1972); dissolved inorganic nitrogen - DIN (nitrite- $\mathrm{N}+$ nitrate- $\mathrm{N}+$ ammonia- $\mathrm{N}$ ); orthophosphate-P (DIP), total dissolved nitrogen (TDN), and total dissolved phosphorus (TDP), determined with the methods described by Strickland and Parsons (1972) and Grasshoff et al. (1983) and suspended particulate material (SPM), measured using the gravimetric method. The content of organic phosphorus (OP) was calculated using the following equation: $\mathrm{OP}=$ TDP - DIP. The value of the N:P ratio was calculated using methods from Redfield (1958).

For statistical analysis and principal component analysis (PCA) was used the statistical software program Statistic 9 (2009).

\section{Results}

\subsection{Hydrology}

The measured water temperatures were typical of a tropical estuary, ranging from $25.3^{\circ} \mathrm{C}$ to $31.1^{\circ} \mathrm{C}$ with a median near $28^{\circ} \mathrm{C}$. Turbidity was higher, especially during low tides and the rainy season, with values ranging from 0.74 NTU (station 4, dry season) to $141.53 \mathrm{NTU}$ (station 3 , rainy season).

The salinity in the Botafogo River estuary (stations 1,2 , and 3) ranged from mesohaline (low tide, rainy season) to euhaline (high tide, dry season). The salinity in the Carrapicho River estuary (stations 5 and 6) had less variance than the Botafogo River estuary, with values ranging from polyhaline (low tide, rainy season) to euhaline (high tide, dry season).

The nutrient concentrations showed great variability, especially in the Botafogo River estuary. The levels of DIN recorded at station 1 during a period of increased rainfall and low tide showed maximum values of 2.89 $\mu$ mol.L $L^{-1}$ ammonia-N, $0.67 \mu$ mol. $L^{-1}$ nitrite-N, and 34.94 $\mu$ mol. $L^{-1}$ nitrate-N. At station 3, DIP showed greater variation with values ranging from 0.02 to $1.74 \mu \mathrm{mol}^{-\mathrm{L}^{-1}}$, this being the maximum value recorded. The maximum TDP values $\left(8.34 \mu \mathrm{mol} . \mathrm{L}^{-1}\right)$ were the result of high levels of OP $\left(8.26 \mu \mathrm{mol} . \mathrm{L}^{-1}\right)$, and the median values $(1.21 \mu \mathrm{mol}$ $\mathrm{L}^{-1}$ and 0.68 , respectively) were higher at the stations of the Botafogo River estuary (stations 1, 2, and 3) and Santa Cruz Channel (station 4). The N:P ratio showed high spatial and seasonal variation. The median values ranged from 2.39:1 to $13.45: 1$, indicating a strong DIN limitation (Table 1).

\subsection{Occurrence of Akashiwo sanguinea}

Akashiwo sanguinea presents pleomorphic cells, which are generally pentagonal in shape, with conical epitheca and bilobed hypotheca. The epitheca and hypotheca are nearly equal in length with a large, spiral girdle that is displaced 0.2 times the length of the cell. The groove does not extend into the epitheca, but does reach deep into the hypotheca. An apical cavity is present that contains numerous yellowish-green chloroplasts distributed in rows radiating from the center of the cell. Akashiwo sanguinea has a length ranging from 30 to $35 \mu \mathrm{m}$, a width ranging from 25 to $29 \mu \mathrm{m}$ and a cross section that is dorsoventrally compressed or circular in nature. The color of the cells ranges from well pigmented to colorless or pale yellow.

Akashiwo sanguinea was recorded at every station in the study area, and cell densities ranged from 5 to $410 \times 10^{3}$ cells. $L^{-1}$. The lowest densities were recorded during the dry season, especially from October to January, at stations 1, 2, 5, 6 and 7. In these areas, the density of the cells varied between 5 and $10 \times 10^{3}$ cells. $\mathrm{L}^{-1}$. The highest densities were observed during the rainy season, mainly during low tide at station 3 (July $210 \times 10^{3}$ cells.L $L^{-1}$; August $410 \times 10^{3}$ cells. $L^{-1}$ ) and station 4 (August $220 \times 10^{3}$ cells. $L^{-1}$ ). It should be noted that the highest density values coincided with low tide events (Figure 2).

\subsection{Statistical Analysis}

The PCA results showed that the first two components explained $58.33 \%$ of the variation in the data (Figure 3 ). Factor $1(42.87 \%)$ showed that the hydrological variability of the estuaries was a result of the heterogeneous characteristics of the sampling stations. The heterogeneous characteristics are highlighted by the contrast between the more saline coastal water, which is warm and contains less SPM and the estuarine waters. Factor 2 (15.46\%) indicated the preference of Akashiwo sanguinea for DIP and TDP. 


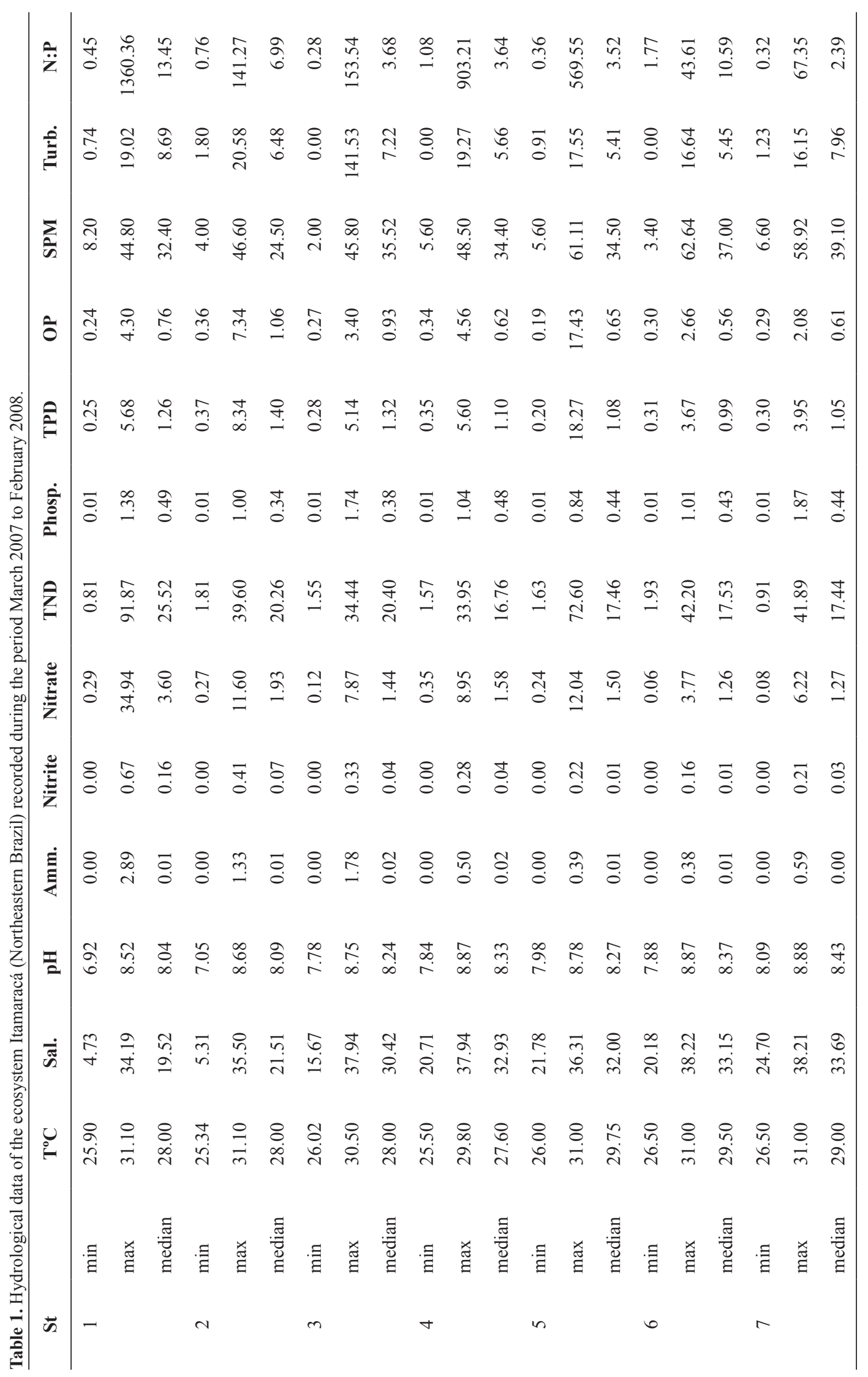



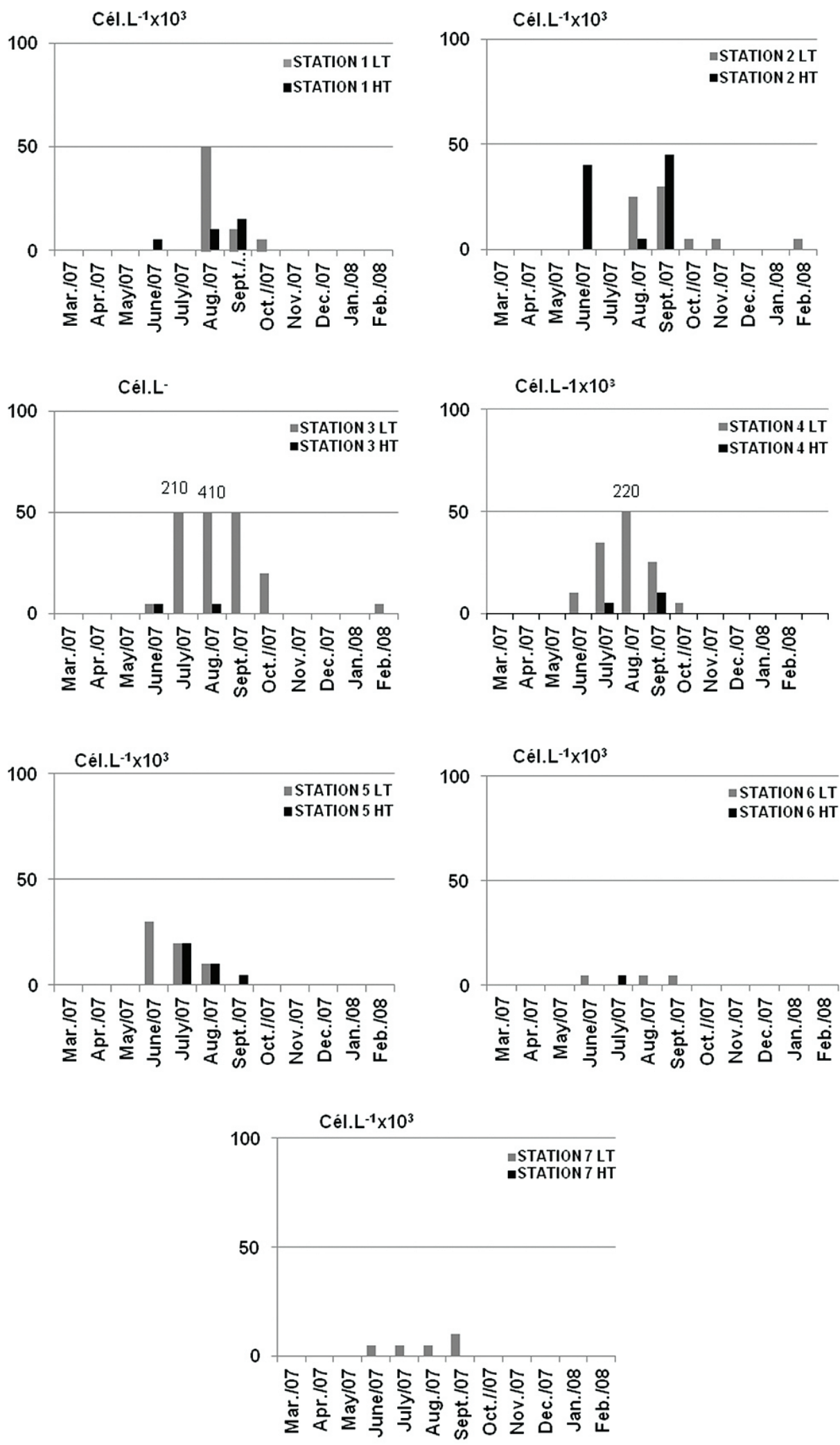

Figure 2. Cellular density of Akashiwo sanguinea in the estuarine waters of Itamaracá Island (Northeastern-Brazil). Seven stations and period from March 2007 to February 2008. 
Table 2. Correlations between Akashiwo sanguinea and the principal hydrological variables in the seven sampling stations during the rainy and dry seasons (March 2007 to February 2008).

\begin{tabular}{lc}
\hline & Akashiwo \\
\hline Akashiwo & 1.0000 \\
Water transparency & -0.4040 \\
$\mathrm{~T}^{\circ} \mathrm{C}$ & -0.2679 \\
Salinity & -0.1365 \\
$\mathrm{NH} 4$ & 0.0790 \\
$\mathrm{NO} 3$ & -0.0347 \\
$\mathrm{TN}$ & -0.0200 \\
$\mathrm{PO} 4$ & 0.1240 \\
$\mathrm{TP}$ & 0.5936 \\
\hline
\end{tabular}

Statistical analysis (Table 2) revealed a significant $(\mathrm{p}=0.05)$ and positive correlation between Akashiwo sanguinea and phosphorous, confirming the organism's need for this nutrient. However, water transparency showed an inverse relationship with the density of Akashiwo sanguinea due to inputs of suspended particulate material (SPM) via stream flow and leaching processes.

\section{Discussion}

In the estuarine ecosystem of Itamaracá (Pernambuco, Northeastern Brazil), Akashiwo sanguinea was found throughout the year and at various stations, however, its density was not uniform throughout the area. The highest cell densities were found in regions with conditions ranging from mesohaline to euhaline. This result confirms the finding by Matsubara et al., (2007) that this is a euryhaline species.

The positive correlation of Akashiwo sanguine with concentrations of DIP and TDP, highlight the importance of the availability of this nutrient for the development of the species. This trend was detected mainly during the rainy season (July and August) when the highest river discharges were recorded, which led to a higher deposition of particulate and dissolved material from the land surface.

The results obtained in the estuarine ecosystem of Itamaracá corroborate the results reported by Panosso and Esteves (1999) that studying the phosphatase activity and phytoplankton dynamics in two tropical coastal lagoons (Imboassica and Cabiúnas Lagoons, Rio de Janeiro, Brazil) refer to restrictions soluble reactive phosphorus in Imboassica Lagoon and highlight the hydrolysis of organic phosphorus by phosphatase activities as the main source of inorganic phosphorus for maintenance of phytoplankton that control the dynamics of $A$. sanguinea and the entire phytoplankton community.

Several other factors have been identified in promoting the occurrence of Akashiwo sanguinea in estuarine areas. Recently, Matsubara et al. (2007) studied the effects of temperature, salinity and irradiance on the growth of $A$. sanguinea in the laboratory. The results showed that the

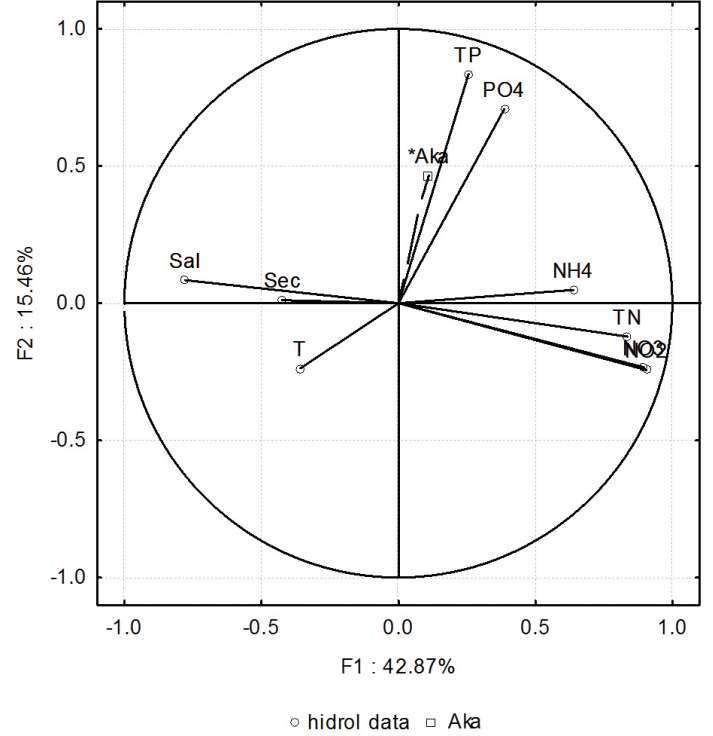

Figure 3. Principal Components Analysis (PCA) linking the hydrological parameters $(\mathrm{t}=$ temperature, $\mathrm{sec}=$ secchi, sal $=$ salinity, $\mathrm{tp}=$ total phosphate, $\mathrm{PO} 4=$ phosphate, $\mathrm{NH}_{4}=$ ammonia, $\mathrm{tn}=$ total nitrate, $\mathrm{NO}_{2}=$ nitrite and $\mathrm{Aka}=$ Akashiwo sanguinea)

irradiance at growth saturation was of $114 \mu \mathrm{mol} \mathrm{m}^{-2} \mathrm{~s}^{-1}$ and that the species was able to grow within the ranges of temperature from 5 to $30^{\circ} \mathrm{C}$ and salinities of 10 to 40 , but the maximum growth rate ( 1.13 divisions/day) was obtained at the combination of $25^{\circ} \mathrm{C}$ and a salinity of 20 . So, they concluded that $A$. sanguinea is a euryhaline, eurythermal organism that grows best in areas with low salinity conditions (mesohaline).

In addition, experiments performed in situ at Lake Tovel (Italy) by Cantonati et al. (2003) revealed that changes in nutrient status (phosphorus enrichment) and meteorological forces (such as light conditions) were key factors in the proliferation and dominance of the species.

Domingos and Menezes (1998) first reported the occurrence of Gymnodinium sanguineum in Barra Lagoon, where they found the species in high frequency and abundance. Barra Lagoon (Rio de Janeiro - Brazil), is a shallow, oligohaline, hypereutrophic tropical lake that is heavily affected by the discharge of domestic sewage. The authors suggested that the dominance of the species might be favoured by swimming velocity and displacement amplitude towards the bottom for nutrient uptake, demonstrated by the positive relation with water transparency.

Melo et al. (2007) studied the temporal and spatial fluctuations of phytoplankton in a tropical coastal lagoon in southeastern Brazil (Imboassica Lagoon, Rio de JaneiroBrazil). They observed that high fluctuations on salinity and nutrient availability were the main factors that control the dynamics of A. sanguinea and the entire phytoplankton community. 
Blooms of A. sanguinea have occurred in different parts of the world and are sometimes related to mortality in fish (Lassus, 1988; Hallegraeff, 1993; Robichaux et al., 1998; Wu et al., 2000). Several records have been documented in Japan (Hirasaka, 1922; Fukuyo et al., 1990), coastal areas of Australia and New Zealand (Hallegraeff, 1991), Mexico (Gómez-Aguirre, 1998), and Hong Kong (Songhui Lu and Hodgkiss, 2004). At Lake Tovel (Italy) the blooms had no toxic effect. However, the accumulation of carotenoids caused the water to turn a bright, intense shade of red, attracting scientists and tourists (Cantonati et al., 2003). Blooms of $A$. sanguinea are common in Chesapeake Bay, United States, where the number of cells may reach $8.8 \mathrm{x}$ $10^{5}$ cells/L (Bockstahler and Coats, 1993). In one bloom in Coyote Bay, Gulf of California, Mexico, cell densities reached $1.0 \times 10^{5}$ cells/L (Kiefer and Lasker, 1975).

In the estuarine ecosystem of Itamaracá, the number of cells/L of $A$. sanguinea remains within levels considered normal for other tropical regions. However, notable increases in cell density that has been recorded during the rainy months, with values close to $500 \times 10^{5}$ cells. $\mathrm{L}^{-1}$ shows that this potentially toxic species is in an environment that is favorable for its development and may be concluded that in the estuarine areas of tropical regions of northeastern Brazil, Akashiwo sanguinea occurs in waters with large variations in salinity and high concentrations of inorganic and organic phosphorus.

Acknowledgements - The authors are grateful to the Conselho Nacional de Desenvolvimento Científico e Tecnológico (CNPq) for the financial support (Proc.n ${ }^{\circ} 484581 / 2006-6$ ).

\section{References}

BOCKSTAHLER, KR. and COATS, DW., 1993. Spatial and temporal aspects of mixotrophy in Chesapeake Bay dinoflagellates. Journal of Eukaryotic Microbiology, vol.40, p.49-60. http://dx.doi. org/10.1111/j.1550-7408.1993.tb04881.x

CANTONATI, M., TARDIO, M., TOLOTTI, M. and CORRADINI, F., 2003. Blooms of the dinoflagellate Glenodinium sanguineum obtained during enclosure experiments in Lake Tovel (N. Italy). Journal Limnology, vol.62, no.1, p.79-87. http://dx.doi.org/10.4081/ jlimnol.2003.79

DAUGBJERG, N., HANSEN, G., LARSEN, J. and MOESTRUP, Ø., 2000. Phylogeny of some of the major genera of dinoflagellates based on ultrastructure and partial LSU rDNA sequence data, including the erection of three new genera of unarmoured dinoflagellates. Phycologia, vol.39, no.4, p.302-317. http://dx.doi. org/10.2216/i0031-8884-39-4-302.1

DOMINGOS, P. and MENEZES, M., 1998. Taxonomic remarks on planktonic phytoflagellates in a hypertrophic tropical lagoon (Brazil). Hydrobiologia, vol.369-370, p.297-313. http://dx.doi. org/10.1023/A:1017097826410

FUKUYO, TH., CHIHARA, M. and MATSUOKA, K., 1990. Red tide organisms in Japan. An illustrated taxonomic guide. Tokyo: Uchida Rokakuho, Co. Ltd. 407 p.

GÓMEZ-AGUIRRE, S., 1998. Red tide occurrences recorded in Mexico from 1980 to 1992. Anales del Instituto de Biología / Serie Zoología, vol.69, no.1, p.13-22.
GÓMEZ, F. and BOICENCO, F., 2004. An annotated checklist of dinoflagellates in the Black Sea. Hydrobiologia, vol.517, no.1-3, p.43-59. http://dx.doi.org/10.1023/B:HYDR.0000027336.05452.07

GRASSHOFF, K., EMRHARDT, M. and KREMLING, K., 1983. Methods of sea water analysis. New York: Verlag Chemie. 419 p.

HALLEGRAEFF, GM., 1991. Aquaculturists guide to harmful Australian microalgae. Hobart: Fishing Industry Training Board of Tasmania, CSIRO Division of Fisheries. 111 p.

-, 1993. A review of harmful algal blooms and their apparent global increase. Phycologia, vol.32, no.2, p.79-99. http://dx.doi. org/10.2216/i0031-8884-32-2-79.1

HIRASAKA, K., 1922. On a case of discolored sea-water. Annotationes Zoologicae Japonenses, vol.10, no.15, p.161-164.

HORNER, RA., GARRISON, DL. and PLUMLEY, FG., 1997. Harmful algal blooms and red tide problems on the U.S. west coast. Limnology and Oceanography, vol.42, no.5, p.1076-1088.

KIEFER, DA. and LASKER, R., 1975. Two blooms of Gymnodinium splendens, an unarmored dinoflagellate. Fishery Bulletin, vol.73, no.3, p.675-678.

KOENING, ML., ESKINAZI-LEÇA, E., NEUMANN-LEITÃO, S. and MACEDO, SJ., 2002. Impactos da construção do Porto de Suape sobre a comunidade fitoplanctônica no estuário do rio Ipojuca (Pernambuco, Brasil). Acta Botânica Brasilica, vol.16, no.4, p.407-420.

LASSUS, P., 1988. Plancton toxique et plancton d'eaux rouges sur les cotes Européennes. Brest: Institut Français de Recherche pour 1'Exploitation de la Mer. $97 \mathrm{p}$

MATSUBARA, T., NAGASOE, S., YAMASAKI, Y., SHIKATA, T., SHIMASAKI, Y., OSHIMA, Y. and HONJO, T., 2007. Effects of temperature, salinity, and irradiance on the growth of the dinoflagellate Akashiwo sanguinea. Journal of Experimental Marine Biology and Ecology, vol.342, no.2, p.226-230. http:// dx.doi.org/10.1016/j.jembe.2006.09.013

MEDEIROS, C. and KJERFVE, B., 1993. Hydrology of a tropical estuarine system: Itamaracá, Brazil. Estuarine, Coastal and Shelf Science, vol.36, no.5, p.495-515. http://dx.doi.org/10.1006/ ecss. 1993.1030

MEDEIROS, C., KJERFVE, B., ARAUJO, M. and NEUMANNLEITÃO, S., 2001. The Itamaracá estuarine ecosystem, Brazil. In SEELIGER, U. and KJERFVE, B. (Ed.). Ecological studies: Coastal Marine Ecosystems of Latin America. Berlin: SpringerVerlag. vol.144, p.71-81.

MELO, S., BOZELLI, RL. and ESTEVES, FA., 2007. Temporal and spatial fluctuations of phytoplankton in a tropical coastal lagoon, southeast Brazil. Brazilian Journal of Biology, vol.67, no.3, p.475-483. PMid:18094830. http://dx.doi.org/10.1590/ S1519-69842007000300012

NAKAMURA, Y., WATANABE, M. and WATANABE, M., 1982. The effect of various environmental factors on the growth yield of red tide algae. III. Gymnodinium splendens. Research Report National Institute for Environmental Studies, vol.30, p.87-93.

PANOSSO, RF. and ESTEVES, AS., 1999. Phosphatase activity and plankton dynamics in two tropical coastal lagoons. Archiv fuer Hydrobiologie, vol.146, no.3, p.341-354.

REDFIELD, AC., 1958. The biological control of chemical factors in the environment. American Journal of Science, vol.46, p.205-221. 
ROBICHAUX, RJ., DORTCH, Q. and WRENN, JH., 1998. Occurrence of Gymnodinium sanguineum in Louisiana and Texas Coastal Waters, 1989-94. NOAA Technical Report NMFS, vol.143, p.19-26.

STEIDINGER, KA. and TANGEN, K., 1997. Dinoflagellates. In: TOMAS, CR. (Ed.). Identifying marine diatoms and dinoflagellates. New York: Academic Press. p.387-584.

STRICKLAND, JDH. and PARSONS, TRA., 1972. A practical handbook of seawater analysis. Bulletin Fisheries Research Board of Canada, vol.125, p.1-205.
SONGHUI, LU. and HODGKISS, IJ., 2004. Harmful algal bloom causative collected from Hong Kong waters. Hydrobiologia, vol.512, no.1-3, p.231-238. http://dx.doi.org/10.1023/ B:HYDR.0000020331.75003.18

WU, Y., ZHOU, C., ZHANG, Y., PU, X. and LI, W., 2000. Evolution and causes of formation of Gymnodinium sanguineum bloom in Yantai Sishili Bay. Oceanologia et Limnologia Sinica, vol.32, no.2, p.159-167. 